\title{
Role of Growth Hormone in Countering the Effects of Anxiety and Depression in Women Undergoing in-vitro Fertilization-Embryo Transfer [Letter]
}

\author{
Abdul Moiz Sahito \\ Dow Medical College, Karachi, Pakistan
}

Correspondence: Abdul Moiz Sahito Dow Medical College, Mission Road, New Labour Colony Nanakwara, Karachi, Sindh, Pakistan

Tel +92-3313682059

Email sahitomoiz@gmail.com

\section{Dear editor}

I have read the article entitled "The analysis of anxiety and depression in different stages of in-vitro fertilization-embryo transfer in couples in China" by Liu et al published in Neuropsychiatric Disease and Treatment. ${ }^{1}$ I want to acknowledge the authors for this successful research article and make some contributions.

In the article, the effect of anxiety and depression on the outcomes of IVF-ET has been studied indicating that there is high incidence of anxiety and depression in couples undergoing IVF-ET, particularly in women. Although the study concluded that there is no significant association between anxiety and depression and IVF-ET outcomes $(p>0.05)$, there is still a need of a much more extensive investigation.

Regarding this matter, I have something to suggest. I think that this study should have included an examination of changes in hormonal index of women involved in the study. While the study conducted by $\mathrm{An}$ et $\mathrm{al}^{2}$ did an examination on the changes in stress influencing the outcomes of IVF via the activation of hypothalamus-pituitary-adrenal (HPA) axis, there is still a need of a thorough study which involves hormones that are part of the HPA axis. In this matter, role of Growth Hormone should be investigated in increasing the efficacy of IVF-ET in women with high level of anxiety and depression. The randomized control trial, conducted by Hart, ${ }^{3}$ conclusively showed that pretreatment with $\mathrm{GH}$ alleviates Oxidative Stress (OS), involved in the pathogenesis of Poor Ovarian Responders (POR), and improves oocyte quality and outcomes of PORs.

Therefore, the potential applications of GH in women with anxiety and depression related issues does warrant attention and should be thoroughly investigated. For this, I suggest that a study consisting of two groups of women diagnosed with clinical anxiety and depression undergoing IVF should be done, with one group pretreated with $\mathrm{GH}$, and both examined to find any conclusive indication that $\mathrm{GH}$ pretreatment increases the efficacy of the IVF-ET procedures by countering the effects of severe anxiety and depression.

\section{Disclosure}

The author reported no conflicts of interest for this communication. 


\section{References}

1. Liu YF, Fu Z, Chen SW, He XP, Fan LY. The analysis of anxiety and depression in different stages of in vitro fertilization-embryo transfer in couples in China. Neuropsychiatr Dis Treat. 2021;17:649. doi:10.2147/NDT.S287198

2. An Y, Wang Z, Ji H, Zhang Y, Wu K. Pituitary-adrenal and sympathetic nervous system responses to psychiatric disorders in women undergoing in vitro fertilization treatment. Fertil Steri. 2011;96 (2):404-408. doi:10.1016/j.fertnstert.2011.05.092
3. Hart RJ. Use of growth hormone in the IVF treatment of women with poor ovarian reserve. Front Endocrinol (Lausanne). 2019;10:500. doi: $10.3389 /$ fendo. 2019.00500

Dove Medical Press encourages responsible, free and frank academic debate. The content of the Neuropsychiatric Disease and Treatment 'letters to the editor' section does not necessarily represent the views of Dove Medical Press, its officers, agents, employees, related entities or the Neuropsychiatric Disease and Treatment editors. While all reasonable steps have been taken to confirm the content of each letter, Dove Medical Press accepts no liability in respect of the content of any letter, nor is it responsible for the content and accuracy of any letter to the editor.

Neuropsychiatric Disease and Treatment

Dovepress

\section{Publish your work in this journal}

Neuropsychiatric Disease and Treatment is an international, peerreviewed journal of clinical therapeutics and pharmacology focusing on concise rapid reporting of clinical or pre-clinical studies on a range of neuropsychiatric and neurological disorders. This journal is indexed on PubMed Central, the 'PsycINFO' database and CAS, and is the official journal of The International Neuropsychiatric Association (INA). The manuscript management system is completely online and includes a very quick and fair peer-review system, which is all easy to use. Visit http://www.dovepress.com/testimonials.php to read real quotes from published authors.

Submit your manuscript here: https://www.dovepress.com/neuropsychiatric-disease-and-treatment-journal 